\title{
Growth and nutritional disorders of coffee cultivated in nutrient solutions with suppressed macronutrients
}

Rilner Alves Flores, Bernardo Melo Montes Nogueira Borges, Hilário Júnior Almeida \& Renato De Mello Prado

To cite this article: Rilner Alves Flores, Bernardo Melo Montes Nogueira Borges, Hilário Júnior Almeida \& Renato De Mello Prado (2016) Growth and nutritional disorders of coffee cultivated in nutrient solutions with suppressed macronutrients, Journal of Plant Nutrition, 39:11, 1578-1588, DOI: $10.1080 / 01904167.2016 .1161777$

To link to this article: https://doi.org/10.1080/01904167.2016.1161777

Accepted author version posted online: 09

May 2016.

Published online: 09 May 2016.

Submit your article to this journal $\pi$

Џll Article views: 140

View Crossmark data ¿

Citing articles: 1 View citing articles $\sqsubset$ 


\title{
Growth and nutritional disorders of coffee cultivated in nutrient solutions with suppressed macronutrients
}

\author{
Rilner Alves Flores ${ }^{a}$, Bernardo Melo Montes Nogueira Borges ${ }^{b}$, Hilário Júnior Almeida ${ }^{b}$, and \\ Renato De Mello Prado ${ }^{b}$

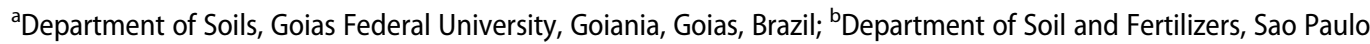 \\ State University, Jaboticabal, Sao Paulo, Brazil
}

\begin{abstract}
The objective was to evaluate the effect of omitting macronutrients in the nutrients solution on growth characteristics and nutritional status of coffee. The treatments were complete nutrients solutions and solutions with nutrient omission: N (nitrogen), P (phosphorus), K (potassium), Ca (calcium), Mg (magnesium) and S (sulfur). The experiment was carried out under greenhouse conditions with 3 replicates in a completely random design. Plant height, number of leaves per plant, stem diameter, relative chlorophyll index, photosynthesis rate, stomatal conductance, transpiration, carbon dioxide $\left(\mathrm{CO}_{2}\right)$ concentration, dry matter, content levels of macronutrients in plant aerial part and root system, and nutritional disorders were evaluated. Macronutrients suppression affected nutrients concentration in many plant parts, inducing the appearance of symptoms characteristic of each nutrient. The most limiting nutrients for coffee plants development were nitrogen and calcium, reflected in the lower dry matter accumulation and nitrogen the most required.
\end{abstract}

\section{ARTICLE HISTORY}

Received 19 December 2012

Accepted 14 December 2014

\section{KEYWORDS}

Coffea arabica L.; nutritional deficiency; mineral nutrition

\section{Introduction}

Brazil is the largest world coffee producer, accounting for $30 \%$ of the international market and the second largest consumer after the United States; however, the national and international markets amplified its requirements concerning quality, increasing the demand for special characteristics of coffee beans. Thereby a new challenge is submitted to Brazilian coffee growers: to keep good yield indexes and good quality in accordance with the new requirements of the purchasing market (Chalfoun and Reis, 2010).

That crop, originally from the subtropical forests of hilly Ethiopia, develops better in regions with average temperatures ranging from 19 to $22^{\circ} \mathrm{C}$, with higher temperatures promoting bud formation and fruit development. However they also promote pest proliferation, increasing infection risks, which may impair the quality of the beverage. Also, the crop is much susceptible to frosts and temperatures below $10^{\circ} \mathrm{C}$ inhibit plant growth (Ricci et al., 2006).

In Brazil the total coffee production in the 2013/2014 cropping season was estimated in 50.15 million $60 \mathrm{~kg}$ coffee processed bags; 75\% Arabic type, and the state of Minas Gerais was the largest producer, with 27.4 million bags (55.1\%), followed by Espirito Santo with 12.6 million bags (24.8\%) (CONAB, 2014).

Hydroponics enables the use of balanced nutrient solutions in the absence or presence of natural or artificial substrates, forming an intensive production system (Rodrigues, 2002).

CONTACT Rilner Alves Flores rilner1@hotmail.com Department of Soils, Goias Federal University, Goiânia highway / New Venice, Km 0, Federal University of Goias - Campus Fern, School of Agronomy, Mailbox 131, Goiania, Goias CEP 74690-900., Brazil. 
Nutritional disorder, either by deficiencies or excesses and/or by misbalance causes the reduction of crops production. That reduction is generally preceded by visually observed symptoms more evident on the leaves, although the production might be potentially impaired even before the appearance of those symptoms (Malavolta et al., 1997). Visual diagnosis of nutrient deficiency associated with information about nutrient contents may be an appropriate auxiliary tool to assess the nutritional status, implying in adequate fertilization recommendation for any crop (Epstein, 1975).

There are few studies restricted to certain nutrients without a concern to assess the relationship of missing nutrient with nutrient buildup, as well as their interaction effects on plant development and the onset of symptoms, as well as to find which macronutrient the plant would be more sensitive to deficiency.

These experiments, while simple, enable to check and correlate the biological events involved with the deficiencies in new genotypes with dissimilar abilities to absorb nutrients. Therefore the objective of this work was to evaluate the effect of the absence of macronutrients in the growth and nutritional status of coffee plants grown in nutrient solution.

\section{Materials and methods}

The experiment was carried out in a green house in the Faculdade de Ciências Agrárias e Veterinárias da Unesp, Jaboticabal campus, state of São Paulo - Brazil using Coffea arabica L., cultivar Caturaí Vermelho IAC 144 grown in 8 liter nutrient solutions pots.

Seven treatments were evaluated: 1: complete nutrient solution ( $\mathrm{N}$ (nitrogen), $\mathrm{P}$ (phosphorus), $\mathrm{K}$ (potassium), Ca (calcium), Mg (magnesium), S (sulfur), B (boron), $\mathrm{Cl}$ (chlorine), $\mathrm{Cu}$ (cooper), $\mathrm{Fe}$ (iron), Mn (manganese), Mo (molybdenum) and Zn (zinc); 2: nitrogen suppression (-N); 3: phosphorus suppression $(-\mathrm{P})$; 4 potassium suppression $(-\mathrm{K})$; 5: calcium suppression $(-\mathrm{Ca})$; 6: magnesium suppression $(-\mathrm{Mg})$ and 7 : sulfur emission $(-\mathrm{S})$. Experiments were arranged in a completely randomized design, with three replicates and pots shifted every week to provide the same temperature, moisture and light conditions for all treatments.

The experiment was installed in a greenhouse (1 August 2011) with 20 days old coffee seedlings transplanted to vases ( 2 seedling per vase) containing the Hoagland and Arnon (1950) solution diluted, in the first week, to $50 \%$ of its usual concentration to the adaption seedling with the solution nutrient and then, starting in the second week, till the end of the experiment, at its usual concentration.

Solutions were prepared with deionized water, replaced every 15 days, and $\mathrm{pH}$ adjusted at $5.5 \pm 0.5$ with sodium hydroxide $(\mathrm{NaOH})$ or hydrochloric acid $(\mathrm{HCl}) 0.1 \mathrm{M}$. To replace the evapotranspired water deionized water was used, and the solution oxygenated continuously with an air compressor.

Fifty six days after transplanting (DAT) plants were harvested and the following parameters determined: plant height, measured from the soil surface to the apex of the last developed leaf; total number of leaves per plant; stem diameter; indirect measurement of the chlorophyll content from the relative chlorophyll index (RCI) in ten leaves per experimental unit, using OPTI-Sciences ${ }^{\circledR}$, model CCM-200 apparatus; net photosynthesis rate; stomata conductance; carbon dioxide $\left(\mathrm{CO}_{2}\right)$ concentration; and transpiration in two leaves per experimental unit, using a portable infrared gas analyzer (IRGA) of open system, model LICOR 6400, following description by dos Santos et al. (2006). Measurements were performed from 8 AM to 3 PM on completely expanded leaves in good sanitary condition. Photosynthetic variables responses to light intensity were determined for photon flux density (FFD) of $500 \mu \mathrm{mol}$ $\mathrm{m}^{-2} \mathrm{~s}^{-1}$, with the foliar chamber adjusted to work with $\mathrm{CO}_{2}$ concentration of $380 \pm 5 \mu \mathrm{mol} \mathrm{mol}^{-1}$, $31 \pm 1^{\circ} \mathrm{C}$ temperature and water $\left(\mathrm{H}_{2} \mathrm{O}\right)$ vapor of $21 \pm \mathrm{mmol} \mathrm{mol}^{-1}$, with leaf area of $1 \mathrm{~cm}^{2}$.

The material collected was washed with deionized water and the aerial part separated from the roots; in order to calculate total dry matter, samples were collected, weighed, dried in an oven at $65^{\circ} \mathrm{C}$, and used for $\mathrm{N}, \mathrm{P}, \mathrm{K}, \mathrm{Ca}, \mathrm{Mg}$ and $\mathrm{S}$ content analysis. The $\mathrm{N}$ content determination was performed by sulfuric acid digestion and distillation (Jackson, 1958); For determination of the nutrients phosphorus $(\mathrm{P})$, potassium $(\mathrm{K})$, calcium $(\mathrm{Ca})$, magnesium $(\mathrm{Mg})$, and sulfur $(\mathrm{S})$ a nitric-perchloric digestion was performed (Johnson and Ulrich, 1959), $\mathrm{P}$ was determined by phosphomobilidate reduction by vitamin $\mathrm{C}$, as described by Braga and Defelipo (1974), potassium (K) by flame photometry, while calcium (Ca) 
and magnesium $(\mathrm{Mg})$ were quantified by atomic absorption spectrophotometry (AOAC, 1975), and sulfur (S) by sulfate turbidimetry (Jackson, 1958). These two variables were used to calculate the nutrient accumulation.

During the experimental period descriptions of the visual symptomatology of nutritional deficiencies were daily recorded in each treatment.

Data were submitted to the analysis of variance and to Tukey test $(\mathrm{p}<0.05)$, using software AgroEstat (Barbosa and Maldonado, 2012). It was decided to indicate the significant difference pointed out by the means comparison test related to treatments with nutrient suppressions and the treatment with full nutrient solution.

\section{Results and discussion}

\section{Nitrogen}

Nitrogen suppression reduced the number of leaves of the vegetative variables evaluated as well as the chlorophyll relative index, net photosynthesis rate and $\mathrm{CO}_{2}$ concentration, only (Table 1).

It was observed that there was a drastic reduction in the net photosynthesis rate and expressive increase in $\mathrm{CO}_{2}$ concentration in the treatment suppressed of nitrogen: 71.3 and $196.8 \%$, respectively. Nitrogen is directly involved in the chlorophyll synthesis and exerts an important role in the synthesis of enzymes (phosphoenolpyruvate carboxylase (PEPC) and ribulose bisphosphate carboxylase-oxygenase), involved in the atmospheric $\mathrm{CO}_{2}$ fixation (Prado, 2008). Thus, a low nitrogen availability to plants may reduce $\mathrm{a}$ and $\mathrm{b}$ chlorophyll concentrations (Cruz et al., 2007), resulting in a lower photosynthetic rate and, consequently to a lower growth, regarding the importance of those pigments for the absorption of photons and electrons transport (Heldt, 1997). Therewith, the dry matter production (aerial part, roots, and consequently in the whole tree) was reduced compared to the treatment with the full solution (Table 2).

Nitrogen suppression reduced foliar contents of $\mathrm{P}, \mathrm{Ca}$ and $\mathrm{S}$, when compared with the full nutrient solution (Table 3). When $\mathrm{N}$ was evaluated in the roots, the full nutrient solution presented $\mathrm{N}$ contents of $34.7 \mathrm{~g} \mathrm{~kg}^{-1}$, while $\mathrm{N}$ suppression reduced its content in the roots to $16.2 \mathrm{~g} \mathrm{~kg}^{-1}$ (Table 3).

That reduction in the vegetative growth variables (number of leaves) associated with nitrogen suppression is widely discussed in the literature due to its importance in plant nutrition. According to Filgueira (2003), nitrogen favors vegetative growth, mass accumulation, increases foliar area, and consequently favors the crop yield potential expression. This is due to the effect of that nutrient in biochemical and physiological processes, as in ionic absorption, photosynthesis, respiration, and cell multiplication and differentiation (Malavolta et al., 1997).

Treatment with the full nutrient solution showed $37.3 \mathrm{~g} \mathrm{~kg}^{-1}$ of $\mathrm{N}$ content in the aerial part, while the treatment with its suppression lowered the content to18.4 $\mathrm{g} \mathrm{kg}^{-1}$ (Table 3). It was also observed

Table 1. Height, number of leaves, stem diameter, chlorophyll relative index (CRI), stomatal conductance, net photosynthesis rate, transpiration, $\mathrm{CO}_{2}$ concentration in coffee plants as a function of macronutrients omission in the nutrient solution.

\begin{tabular}{|c|c|c|c|c|c|c|c|c|}
\hline \multirow[b]{2}{*}{ Treatment } & \multirow[b]{2}{*}{$\begin{array}{l}\text { Height } \\
\mathrm{cm}\end{array}$} & \multirow[b]{2}{*}{$\begin{array}{l}\text { Number } \\
\text { of leaves }\end{array}$} & \multirow[b]{2}{*}{$\begin{array}{l}\text { Stem diameter } \\
\mathrm{mm}\end{array}$} & \multirow[b]{2}{*}{ CRI } & \multicolumn{4}{|c|}{$\mathrm{mmol} \mathrm{m} \mathrm{m}^{-2} \mathrm{~s}^{-1}$} \\
\hline & & & & & $\begin{array}{c}\text { Stomatal } \\
\text { conductance }\end{array}$ & $\begin{array}{c}\text { Net } \\
\text { photosynthesis rate }\end{array}$ & Transpiration & $\begin{array}{c}\mathrm{CO}_{2} \\
\text { concentration }\end{array}$ \\
\hline $\begin{array}{l}\text { Nutrient } \\
\text { solution }\end{array}$ & 41.3 & 46.3 & 4.7 & 51.7 & 0.21 & 11.5 & 2.4 & 90.4 \\
\hline$-\mathrm{N}$ & 37.0 & $28.0^{*}$ & 4.5 & $23.7^{*}$ & 0.14 & $3.3^{*}$ & 4.1 & $268.3^{*}$ \\
\hline$-P$ & 40.3 & $41.3^{*}$ & 4.5 & $27.1^{*}$ & 0.18 & 8.4 & 5.6 & $232.9^{*}$ \\
\hline$-\mathrm{K}$ & 38.7 & $41.0^{*}$ & 3.9 & 44.0 & $0.08^{*}$ & $1.4^{*}$ & 2.7 & $284.0^{*}$ \\
\hline$-\mathrm{Ca}$ & 37.7 & $33.7^{*}$ & 4.4 & $33.3^{*}$ & 0.12 & $8.3^{*}$ & 3.9 & 191.9 \\
\hline$-M g$ & 37.7 & 44.0 & 4.5 & $30.6^{*}$ & 0.14 & $7.0^{*}$ & 4.5 & $211.0^{*}$ \\
\hline$-S$ & 38.7 & $39.7^{*}$ & 4.2 & $38.3^{*}$ & $0.09^{*}$ & $5.1^{*}$ & 3.3 & $224.2^{*}$ \\
\hline DMS & 5.34 & 4.42 & 0.98 & 9.30 & 0.11 & 3.11 & 3.81 & 101.94 \\
\hline C.V.\% & 4.82 & 3.95 & 7.78 & 9.15 & 29.17 & 16.90 & 35.06 & 16.60 \\
\hline
\end{tabular}

*Significant and lower than the check treatment in the column according to the Tukey's test at the level of 5\% of probability. 
Table 2. Dry matter production of coffee plants as a function of macronutrients omission in the nutrients solution.

\begin{tabular}{lccc}
\hline & \multicolumn{2}{c}{ Dry matter } \\
\cline { 2 - 4 } Treatment & Aerial part & $\begin{array}{c}\text { Roots } \\
\text { g by plant }\end{array}$ & Whole plant \\
\hline Nutrient solution & 11.4 & 3.2 & 14.6 \\
$-\mathrm{N}$ & $6.1^{*}$ & $2.4^{*}$ & $8.5^{*}$ \\
$-\mathrm{P}$ & 10.3 & $1.1^{*}$ & 11.4 \\
$-\mathrm{K}$ & 10.1 & $1.4^{*}$ & 11.5 \\
-Ca & $8.3^{*}$ & $1.4^{*}$ & $9.7^{*}$ \\
-Mg & 10.5 & $1.6^{*}$ & 12.1 \\
-S & 10.0 & $1.3^{*}$ & 11.3 \\
DMS & 2.87 & 0.41 & 3.12 \\
C.V.\% & 10.54 & 8.17 & 9.67 \\
\hline
\end{tabular}

* Significant and lower than the check treatment in the column according to the Tukey's test at the level of $5 \%$ of probability.

that only in the treatment with nitrogen suppression the nitrogen content of the leaves was ranked as deficient when compared to those obtained by van Raij (2011) (23-32 $\left.\mathrm{g} \mathrm{kg}^{-1}\right)$. These results demonstrated that the contents obtained in the treatments with nitrogen full doses were sufficient to supply the crop requirement for that nutrient.

Nitrogen suppression reduced macronutrients content in the aerial part, roots and whole plant (Table 4). It was also observed that the suppression of the nitrogen responsible for the reduction in nutrients absorption (Table 4) was also reflected in the coffee plant physiological and growth variables (Table 1) and induced the appearance of visual symptoms, such as the uniform yellowing of older leaves.

According to Malavolta et al. (1997), that symptom is associated with low chlorophyll production, which took place because the relative chlorophyll index of the full nutrient solution treatment was 51.7, and in the treatment with $\mathrm{N}$ suppression was 23.7 (Table 1). Nitrogen deficiency in coffee plantations may cause decrease in plants growth and generalized chlorosis (yellowing) of leaves. As nitrogen is quite mobile in the phloem, symptoms of shortage start in the older leaves first (Martinez et al., 2008).

Table 3. Macronutrients content in the aerial part and roots in coffee plants, as a function of macronutrients omission in the nutrient solution.

\begin{tabular}{|c|c|c|c|c|c|c|}
\hline \multirow[b]{2}{*}{ Treatment } & \multicolumn{6}{|c|}{$\mathrm{g} \mathrm{kg}^{-1}$} \\
\hline & $\mathrm{N}$ & $P$ & $\mathrm{~K}$ & $\mathrm{Ca}$ & $\mathrm{Mg}$ & $S$ \\
\hline & \multicolumn{6}{|c|}{ Aerial plant } \\
\hline Nutrient solution & 37.3 & 2.8 & 15.3 & 10.1 & 2.6 & 1.3 \\
\hline$-\mathrm{N}$ & $18.4^{*}$ & $2.6^{*}$ & 14.6 & $8.7^{*}$ & 2.4 & $0.8^{*}$ \\
\hline$-P$ & 33.6 & $2.1^{*}$ & 14.8 & $7.6^{*}$ & $2.0^{*}$ & 1.2 \\
\hline$-K$ & 33.2 & 2.7 & $7.2^{*}$ & $7.9^{*}$ & $2.1^{*}$ & $1.1^{*}$ \\
\hline$-\mathrm{Ca}$ & 34.0 & 2.8 & $13.0^{*}$ & $2.6^{*}$ & $2.2^{*}$ & 1.2 \\
\hline$-M g$ & 35.3 & $1.0^{*}$ & $4.9^{*}$ & $2.6^{*}$ & $0.3^{*}$ & $0.6^{*}$ \\
\hline$-S$ & 35.0 & $2.4^{*}$ & $13.5^{*}$ & $9.1^{*}$ & $2.1^{*}$ & $0.5^{*}$ \\
\hline DMS & 7.66 & 0.20 & 1.06 & 0.84 & 0.29 & 0.19 \\
\hline \multirow[t]{2}{*}{ C.V.(\%) } & 8.27 & 2.98 & 3.11 & 4.25 & 5.19 & 6.90 \\
\hline & \multicolumn{6}{|c|}{ Roots } \\
\hline Nutrient solution & 34.7 & 3.2 & 19.6 & 5.9 & 3.5 & 3.2 \\
\hline$-\mathrm{N}$ & $16.2^{*}$ & 3.1 & 18.7 & 5.5 & 3.4 & 3.0 \\
\hline$-P$ & 32.6 & $1.6^{*}$ & 18.9 & 5.8 & $2.7^{*}$ & 3.1 \\
\hline$-\mathrm{K}$ & 31.6 & $2.5^{*}$ & $9.9^{*}$ & 5.9 & 3.5 & $2.9^{*}$ \\
\hline$-\mathrm{Ca}$ & 30.4 & 2.8 & 18.5 & $2.8^{*}$ & $3.2^{*}$ & $2.9^{*}$ \\
\hline$-M g$ & 34.3 & $2.4^{*}$ & 18.0 & 5.7 & $1.1^{*}$ & $2.7^{*}$ \\
\hline$-S$ & 31.1 & 3.1 & 17.8 & $5.1^{*}$ & $1.5^{*}$ & $2.3^{*}$ \\
\hline DMS & 5.79 & 0.46 & 4.49 & 0.60 & 0.32 & 0.18 \\
\hline C.V.(\%) & 6.72 & 6.11 & 9.06 & 4.00 & 4.13 & 2.15 \\
\hline
\end{tabular}

\footnotetext{
* Significant and lower than the check treatment in the column according to the Tukey's test at the level of $5 \%$ of probability.
} 
Table 4. Macronutrients accumulation in the aerial part, roots, and in the entire coffee plant as a function of macronutrients omission in the nutrient solution.

\begin{tabular}{|c|c|c|c|c|c|c|}
\hline \multirow[b]{2}{*}{ Treatment } & \multicolumn{6}{|c|}{ mg by plant } \\
\hline & $\mathrm{N}$ & $P$ & K & $\mathrm{Ca}$ & $\mathrm{Mg}$ & $S$ \\
\hline & \multicolumn{6}{|c|}{ Aerial plant } \\
\hline Nutrient solution & 423.1 & 32.5 & 174.1 & 114.9 & 29.5 & 15.0 \\
\hline$-\mathrm{N}$ & $113.7^{*}$ & $15.7^{*}$ & $88.7^{*}$ & $52.7^{*}$ & $14.1^{*}$ & $5.1^{*}$ \\
\hline$-P$ & 344.5 & $22.0^{*}$ & 152.6 & $78.3^{*}$ & $20.6^{*}$ & 12.5 \\
\hline$-K$ & 335.0 & 27.2 & $72.8^{*}$ & $80.0^{*}$ & $21.2^{*}$ & $11.1^{*}$ \\
\hline$-\mathrm{Ca}$ & $281.9^{*}$ & $23.3^{*}$ & $107.1^{*}$ & $21.2^{*}$ & $17.9^{*}$ & $9.5^{*}$ \\
\hline$-M g$ & 370.1 & $10.7^{*}$ & $51.1^{*}$ & $27.3^{*}$ & $3.1^{*}$ & $6.6^{*}$ \\
\hline$-S$ & 355.1 & $24.7^{*}$ & 136.8 & 92.4 & $21.3^{*}$ & $5.4^{*}$ \\
\hline DMS & 90.88 & 6.93 & 39.38 & 23.68 & 6.67 & 3.76 \\
\hline \multirow[t]{2}{*}{ C.V.(\%) } & 10.00 & 10.87 & 12.30 & 12.42 & 12.77 & 14.09 \\
\hline & \multicolumn{6}{|c|}{ Roots } \\
\hline Nutrient solution & 110.4 & 10.1 & 62.6 & 18.9 & 11.3 & 10.1 \\
\hline$-\mathrm{N}$ & $38.7^{*}$ & $7.3^{*}$ & $44.5^{*}$ & $13.1^{*}$ & $8.2^{*}$ & $7.2^{*}$ \\
\hline$-P$ & $36.9^{*}$ & $1.8^{*}$ & $21.7^{*}$ & $6.6^{*}$ & $3.1^{*}$ & $3.5^{*}$ \\
\hline$-\mathrm{K}$ & $43.2^{*}$ & $3.5^{*}$ & $13.5^{*}$ & $8.0^{*}$ & $4.8^{*}$ & $3.9^{*}$ \\
\hline$-\mathrm{Ca}$ & $43.3^{*}$ & $4.0^{*}$ & $26.3^{*}$ & $3.9^{*}$ & $4.5^{*}$ & $4.1^{*}$ \\
\hline$-M g$ & $54.0^{*}$ & $3.7^{*}$ & $38.4^{*}$ & $8.9^{*}$ & $1.7^{*}$ & $4.3^{*}$ \\
\hline$-S$ & $40.6^{*}$ & $3.8^{*}$ & $23.2^{*}$ & $6.6^{*}$ & $1.9^{*}$ & $2.9^{*}$ \\
\hline DMS & 12.39 & 1.16 & 10.16 & 3.15 & 1.34 & 1.37 \\
\hline \multirow[t]{2}{*}{ C.V.(\%) } & 8.26 & 8.28 & 11.29 & 11.68 & 9.21 & 9.27 \\
\hline & \multicolumn{6}{|c|}{ Whole plant } \\
\hline Nutrient solution & 533.5 & 42.6 & 236.7 & 133.8 & 40.8 & 25.1 \\
\hline$-\mathrm{N}$ & $152.4^{*}$ & $23.0^{*}$ & $133.2^{*}$ & $65.8^{*}$ & $22.3^{*}$ & $12.3^{*}$ \\
\hline$-P$ & $381.4^{*}$ & $23.8^{*}$ & $174.3^{*}$ & $84.9^{*}$ & $23.7^{*}$ & $16.0^{*}$ \\
\hline$-K$ & $378.2^{*}$ & $30.7^{*}$ & $86.3^{*}$ & $88.0^{*}$ & $27.0^{*}$ & $15.0^{*}$ \\
\hline$-\mathrm{Ca}$ & $325.2^{*}$ & $27.3^{*}$ & $133.4^{*}$ & $25.1^{*}$ & $22.4^{*}$ & $13.6^{*}$ \\
\hline$-\mathrm{Mg}$ & $424.1^{*}$ & $14.4^{*}$ & $79.5^{*}$ & $36.2^{*}$ & $4.8^{*}$ & $10.9^{*}$ \\
\hline$-S$ & $395.7^{*}$ & $28.5^{*}$ & 160.0 & $99.0^{*}$ & $23.2^{*}$ & $8.3^{*}$ \\
\hline DMS & 95.99 & 7.57 & 45.59 & 25.49 & 7.56 & 4.54 \\
\hline C.V.\% & 9.07 & 9.74 & 11.12 & 11.71 & 11.32 & 10.95 \\
\hline
\end{tabular}

* Significant and lower than the check treatment in the column according to the Tukey's test at the level of 5\% of probability.

Guimarães and Reis (2010) reported nitrogen deficiencies characterized by yellowing of older leaves, especially in dry spells and fruit development, besides presenting "dieback." Dieback occurs when leaves have less than $2.5 \%$ of $\mathrm{N}$ and less than $1.5 \%$ of $\mathrm{K}$. Defoliation of median stems or chicken neck. It may also occur in a way that the absence of chicken neck occurs when leaves have from 3.5 to $4.0 \%$ $\mathrm{N}$, and small fruits drop easily due to $\mathrm{N}$ deficiency. Bragança et al. (2007) reported that nitrogen deficiency is initially present in areas between the veins of older leaves, which presented a greenish shade and irregular spots, showing a yellowish color with the evolution of the deficiency.

\section{Phosphorus}

Coffee trees not receiving phosphorus in the nutrient solution presented reduction in the number of leaves, relative chlorophyll index and in $\mathrm{CO}_{2}$ concentration (Table 1), resulting in a lower dry matter production in the roots, compared to treatments with the full nutrient solution (Table 2).

It was observed that the $\mathrm{CO}_{2}$ internal concentration increased $157.6 \%$ with phosphorus suppression. Trees with phosphorus suppression had losses in the roots dry matter production, due to the importance of that element in plant nutrition, as it is linked to plant structural function in the transfer and storage of the energy process (Malavolta, 1989), affecting metabolic processes such as protein and nucleic acid synthesis (Mengel and Kirkby, 1987).

Phosphorus suppression reduced this nutrient content in the aerial part $(25.0 \%)$ as in the roots (50.0\%) (Table 3). The full nutrient solution showed $\mathrm{P}$ content within the rate considered adequate by 
van Raij (2011) (1.2-2.0 $\left.\mathrm{g} \mathrm{kg}^{-1}\right)$, except for the treatment suppressed of $\mathrm{Mg}$, which showed $1.0 \mathrm{~g} \mathrm{~kg}^{-1}$ of $\mathrm{P}$ in the areal part.

It was also observed that the treatment with $\mathrm{P}$ absence reduced other nutrient contents ( $\mathrm{Ca}$ and $\mathrm{Mg}$ in the leaves and $\mathrm{Mg}$ in the roots) when compared to the full nutrient solution treatment (Table 3); reduced the content of that nutrient in the aerial part (32.2\%), in the roots $(82.2 \%)$ and in the entire plant (44.45\%) besides reducing the content of all other nutrients in the aerial part, in the roots and in the entire plant, with the exception of $\mathrm{N}, \mathrm{K}$ and $\mathrm{S}$ in the aerial part (Table 4).

This result is due to the role of phosphorus as a source of energy and energy transfer as adenosine triphosphate (ATP) to the active nutrient's absorption process, and, in its absence, the nutrients absorption is impaired, affecting the crop development (Malavolta, 2006). Phosphorus absence also provoked losses in the vegetative development due to a lesser absorption of that nutrient resulting in the appearance of visual symptoms such as stunted plants with darker green color old leaves.

Phosphorus deficiency may result in less plant growth, and, frequently, dark green color in old leaves (Martinez et al., 2008). Bragança et al. (2007) reported that phosphorus absence may impair growth, development and production, with symptoms of deficiency shown in older leaves with purple spots between leaf veins. Guimarães and Reis (2010) reported that the first evidence of phosphorus absence is reduction in plant growth and old leaves affected before the new ones, due to P mobility into the plant that turns leaves yellow and even reddish. They also observed premature leaf fall, that could be total, resulting in low yield and poor quality product.

\section{Potassium}

Coffee plants not supplied with potassium presented reduction in the number of leaves (11.4\%), stomata conductivity (61.9\%) and an increase in the internal $\mathrm{CO}_{2}$ concentration $(214.2 \%)$ (Table 1); resulting in a lower roots dry matter production (56.3\%) when compare with the full nutrient solution treatment (Table 2). Potassium has not structural role in plants; however, it is an important enzyme activator and is linked with chorine for the role of osmotic regulation in plants, controlling stomata opening and closing (Malavolta, 2006), explaining, in large extent the results obtained in this study, with a $62 \%$ reduction on stomata conductance, due to its omission in the nutrient solution.

Absence of $\mathrm{K}$ reduced the contents of that nutrient in the aerial part (52.9\%) and in the roots (49.5\%), respectively (Table 3), when compared to the full nutrient solution treatment. It was also observed that all treatments would be nutritionally deficient in potassium if compared with the adequate content of $\mathrm{K}$ in the leaves stated by van Raij (2011) (18-25 $\mathrm{g} \mathrm{kg}^{-1}$ ). Potassium absence also reduced other nutrients contents $(\mathrm{Ca}, \mathrm{Mg}$ in the leaves and $\mathrm{P}$ and $\mathrm{S}$ in the roots), when compared with the full nutrient solution treatment (Table 3).

Potassium absence enabled to observe a significant reduction in all other macronutrients content, both in the aerial part and roots, and consequently in the entire plant, with the exception of $\mathrm{N}$ and $\mathrm{P}$ in the aerial part (Table 4). These results are in agreement with the literature, since potassium is bound with the function of changes in the conformation of molecules within the plant, which increases the exposure of the active sites for binding to the substrate (Malavolta, 2006). In general, conformational changes induced by $\mathrm{K}^{+}$in enzymes increase the catalytic enzymes rate $\left(\mathrm{V}_{\text {máx. }}\right)$ and in many cases also the affinity for substrate $\left(\mathrm{K}_{\mathrm{m}}\right)$ (Evans and Wildes, 1971). However, the omission of potassium in the nutrient solution may promote significant reductions in the absorption of various nutrients by the plant.

Losses due to $\mathrm{K}$ absence in the solution, in the growth impairment and in nutrient absorption, previously reported, induced the appearance of visual symptoms, as chlorosis of old leaves borders, followed by necrosis. Similar symptoms were reported by Martinez et al. (2008) in coffee plants with deficiency of $\mathrm{K}$ showing chlorosis followed by necrosis of older leaves, progressing to the center of leaves veins. The effect of $\mathrm{K}$ deficiency in older leaves is attributed to the intense redistribution of the nutrient in the plants (Mengel and Kikby, 1987).

Martinez et al. (2008) also reported that potassium deficiency provokes wilting and breakage of stems and that border necrosis extends to young leaves, resulting in higher protein degradation and accumulation of basic amines and induction of enzymes regulating the putrescine synthesis 
accumulated in the leaves edges, as the deficiency progressed. Guimarães and Reis (2010) reported that potassium deficiency in coffee plants may provoke chlorosis and necrosis of older leaves and "dieback", besides giving rise to small and empty fruits. These symptoms are due, especially because that nutrient exerts important roles in the synthesis of the carbohydrates in the leaves, and in its transfer to fruits and other plant organs. Passos (1999) also adds that potassium is necessary for chlorophyll development.

Bragança et al. (2007) also reported that potassium deficiency in coffee plants is responsible for higher soluble carbohydrates and reducer sugars pile up in the tissues, with symptoms characteristics of necrosis or older leaves borders darkening, promoted by starch biosynthesis reduction through starch synthesis activation.

\section{Calcium}

Coffee plant lacking calcium had fewer number of leaves, low net chlorophyll index and low chlorophyll rate (Table 1), resulting in lower dry matter production in the aerial part, roots and in the entire plant (Table 2). In roots, calcium suppression reduced $56.3 \%$ of the dry matter, which could be explained by calcium role associated with pectins through calcium pectate. Typically, when cells grow, the surface of contact between them elongates, increasing the need for calcium supply (calcium pectates) to form pectin, giving elongation to the cell wall to reach the final size where lignin is deposited, making cell walls more rigid (Mengel and Kikby, 1987; Prado, 2008). Also, reduction of dry matter caused by Ca suppression was $27.2 \%$ in the aerial part and $33.6 \%$ in the entire plant, compared to the full solution treatment. Moreover, the calcium from calcium pectates is also part of the middle lamella (space between two adjacent cells) that have "cementing" function, namely connecting the neighboring cells (Prado, 2008). This effect of calcium in the organization of the middle lamella may influence the texture, firmness and fruit ripening (Hanson et al., 1993) and reduces the rate of degradation of vitamin $\mathrm{C}$, ethylene and $\mathrm{CO}_{2}$ production and the incidence of postharvest diseases (Conway and Sams, 1983).

Calcium suppressed treatment reduced Ca content compared with the full nutrient solution treatment, both in the aerial part (74.3\%) and in the roots (52.5\%) respectively (Table 3).Yet, according to the adequate contents of Ca suggested by van Raij (2011) (10 to $\left.15 \mathrm{~g} \mathrm{~kg}^{-1}\right)$ plants with the full solution had adequate values, while the treatment with $\mathrm{Ca}$ suppression was Ca deficient.

Calcium suppression reduced $\mathrm{K}$ and $\mathrm{Mg}$ contents in the aerial part and $\mathrm{Mg}$ and $\mathrm{S}$ in the roots (Table 3). Similarly, the same occurred with nutrients content in the entire plant. When Ca was suppressed, the content of this element was reduced in the aerial part (81.5\%) and in the roots (79.4\%), and consequently in the entire plant $(81.2 \%)$, compared to plants grown in the added calcium nutrient solution. Also, calcium suppression reduced all other macronutrients in the aerial part, roots and whole plant (Table 4). These results can be explained due to the roles performed by calcium in the cell membrane, once calcium interconnects phosphate/carboxylic phospholipid groups and confers stability to proteins, particularly the peripherals (Marschner, 1995), and for activating ATPases. Therefore, calcium is an important element for membrane stability and for ions selective absorption.

The depressive effects of calcium absence in the biological variables and nutrients absorption led to the emergence of visible nutritional disorders, such as leaves with irregular shapes, spots with necrotic stains between leaves veins and death of buds, starting from the tips of the leaves and roots. In plants with calcium deficiency cells wall disintegration and collapse of young tissues was observed besides the emergence of young leaves with whitish borders. As the nutritional deficiency progressed, symptom also progressed to interveinal and marginal chlorosis, with veins showing darker green tone. Also, given its role in cellular division and its mobility in the phloem, Ca shortage led to meristem death, severely affecting roots growth and deepening (Martinez et al., 2008). These results are due to the role of calcium, since at complexing with IAA (indole acetic acid) it may promote the elasticity of the cell wall, stimulating cell growth (Rains, 1976). Some authors suggest that AIA is involved in the transport of Ca to the apical regions of the plant (root or branch); thus, the decrease in the level of auxin causes Ca deficiency in these tissues. Therefore, to maintain optimum root growth of crops it is necessary to maintain a minimum concentration of $\mathrm{Ca}$ in the soil, from 2.5 to $8.0 \mathrm{mmol}_{\mathrm{c}}$ $\mathrm{dm}^{-3}$ (Adams and Moore, 1983). 
Bragança et al. (2007) mentioned that due to the immobility of calcium in the phloem, symptoms of this nutrient deficiency in coffee plants include border and interveinal chlorosis of younger leaves, as well as reduction in the apical meristems growth. Guimarães and Reis (2010) observed that the symptoms of calcium deficiency in coffee plants are evidenced by roots poorly developed and inefficient in uptake water and minerals; with low root system development, death of end buds and turning plants more droughts susceptible, because the absence of $\mathrm{Ca}$ limits roots development and water uptake.

\section{Magnesium}

Coffee plants grown with $\mathrm{Mg}$ suppression presented reduction in the relative chlorophyll index (40.8\%) net photosynthesis rate $(39.1 \%)$ and an increase in plant internal $\mathrm{CO}_{2}$ concentration (133.4\%) (Table 1), compared to the full nutrient solution treatment. A reduction in dry matter production in the roots (50\%) was also observed (Table 2). These results are due to the role of magnesium in plants, since about $20 \%$ of the leaf total $\mathrm{Mg}$ is in the chloroplasts. From that total, $20 \%$ are in the chlorophyll and the remaining in ionic form. Therefore, magnesium deficiency induces decreases in the chlorophyll synthesis and, consequently, in the photosynthetic rate (Prado, 2008). $\mathrm{CO}_{2}$ concentration increase in the plant occurs because $\mathrm{Mg}$ acts as activator of the enzyme reactions for the regeneration of ribulose diphosphate which consists of $\mathrm{CO}_{2}$ acceptor, or "sugar which accepts the fixed photosynthetic $\mathrm{CO}_{2}$, which occurs at the beginning of the Calvin cycle in the chloroplast (Pierce, 1986). Thus, by taking part in reactions involving $\mathrm{CO}_{2}$ fixation, the lack of $\mathrm{Mg}$ can inhibit photosynthesis even in the presence of chlorophyll. Thus, by reducing the enzymatic action due to magnesium deficiency, there is low production or regeneration of ribulose diphosphate; a carbon skeleton, which receives the fixed $\mathrm{CO}_{2}$.

That treatment promoted reduction in Mg content in the aerial part (88.5\%) and roots (15.6\%) (Table 3) compared to the full nutrient solution treatment. Other nutrient contents were also reduced in the $\mathrm{Mg}$ suppressed treatment ( $\mathrm{P}, \mathrm{Ca}, \mathrm{Mg}$ and $\mathrm{S}$ in the aerial part, and $\mathrm{P}, \mathrm{Mg}$ and $\mathrm{S}$ in the roots), compared with the full solution treatment (Table 3). Magnesium contents in the aerial part in the treatment with full solution showed values below the adequate, considered deficient, as reported by van Raij (2011) ( 3 to $5 \mathrm{~g} \mathrm{~kg}^{-1}$ ).

Treatment suppressed of $\mathrm{Mg}$ reduced the content of this nutrient in the aerial part (89.5\%), roots (85.0\% and entire plant (88.2\%). Also, there was reduction in the contents of all other nutrients in the aerial part, roots and entire plant with exception of nitrogen in the aerial part, compared to treatment with full solution (Table 4).

Magnesium omission was responsible for impairments in the vegetative development, as previously reported; it induced the appearance of symptoms of nutritional disorders, with plants showing chlorosis, starting on older leaves veins. These symptoms were similar to those reported by Martinez et al. (2008) which verified yellowing and interveinal chlorosis on alder leaves, which might progress to necrosis. It is important to point out that those symptoms were diagnosed at the end of the evaluations period, once in the beginning of plants development the amount of this nutrient in the plant prevented the appearance of visual symptoms.

Guimarães and Reis (2010) quote magnesium as responsible for chlorophyll formation and by plants green color, and once it is mobile in the plants, it may translocate easily from older tissues to younger plant parts. Also, the same authors stated that the symptoms of magnesium deficiency in coffee plants occur primarily in older leaves with color degradation between leaves veins; generally starting on the border and apex, progressing to the center, and also stated that low content of $\mathrm{Mg}$ in leaves may reduce photosynthesis production and plant growth. Bragança et al. (2007) affirmed that magnesium deficiency symptoms in coffee plant start with interveinal chlorosis on older leaves, and may progress to younger leaves, especially because magnesium exerts fundamental role in photosynthesis formation and photo assimilates production, necessary for high harvest indexes.

\section{Sulfur}

Absence of sulfur in the solution caused reductions in the number of leaves (14.3\%), relative chlorophyll index (25.9\%), stomata conductance (57.1\%), net photosynthesis rate $(55.7 \%)$, and increases in $\mathrm{CO}_{2}$ concentration (148\%) (Table 1), resulting in less dry matter production in the roots (59.4\%) (Table 2), when 
compared to the full nutrient solution treatment. It was also observed those reductions in stomata conductance and net photosynthesis rate may be explained because $S$ is a component of ferrodoxin; a low molecular weight protein acting in oxireduction reactions in photosynthesis (Prado, 2008).

It is important to emphasize that plants subjected to $\mathrm{S}$ omission showed reduction in this nutrient content in the aerial part $(61.5 \%)$ and roots $(28.1 \%)$ compared to the full nutrient solution treatment (Table 3). Sulfur contents in the aerial part, both in the treatment with full nutrient solution as in the treatment omitted of S presented values below the adequate range suggested by van Raij (2011) (1.5 to $\left.2.0 \mathrm{~g} \mathrm{~kg}^{-1}\right)$. These differences might be attributed to genotype, type of leaves collected and distinct cultivation conditions.

Sulfur omission reduced $\mathrm{P}, \mathrm{K}, \mathrm{Ca}$ and $\mathrm{Mg}$ contents in the aerial part and $\mathrm{Ca}$ and $\mathrm{Mg}$ in the roots (Table 3) besides reducing $S$ content in the aerial part (64.0\%), in then roots (71.3\%) and in the entire plant (66.9\%) compared to plants grown in the full solution (Table 4).

As a function of dry matter and nutrient absorption reduction due to $\mathrm{S}$ absence in the solution, nutritional disorders were observed in the last week of evaluation such as the emergence of small leaves, with curling borders, as well as chlorosis in young leaves. These results were similar to those reported by Martinez et al. (2008), which verified generalized chlorosis very similar to that deriving from nitrogen deficiency. However, in the $\mathrm{S}$ case the chlorosis started in young leaves due to the low mobility of this nutrient in the phloem. Bragança et al. (2007) considered chlorosis between younger leaves nerves as symptoms of sulfur deficiency. Guimarães and Reis (2010) also stated that sulfur deficiency also appears in younger leaves, with chlorosis between veins; shortening of internodes and defoliation. The same authors also stated that in less severe deficiency situation, visual symptoms are not shown, but production and quality are affected.

Schnug et al. (1985) carried out a study in 51 coffee farmers (Coffea canephora var. Robusta), with coffee age between 6 and 20 years old. In this study, it was evaluated the soil fertility, the mineral nutrition of this plants, and also the relationship between these properties. It was not observed in the sample soil deficiency of iron $(\mathrm{Fe})$, manganese $(\mathrm{Mn})$, zinc $(\mathrm{Zn})$ and cupper $(\mathrm{Cu})$, however, in an analyse of the plant nutritional state, the major deficiency was $\mathrm{Zn}$, which present an relationship $\mathrm{Zn}: \mathrm{Cu} 1: 2.6$, while the normal for the region is $5: 1$. Same authors related that there are not a positive relationship between the soil nutrient content and the nutrient present in the plant (coffee). At the end of the study, the following decreasing order of nutritional deficiency in the plant of coffee was found: $\mathrm{Zn}>\mathrm{Ca}>\mathrm{P}>\mathrm{N}>\mathrm{Fe}>\mathrm{Mg}>\mathrm{P}>\mathrm{S}>\mathrm{Mn}=\mathrm{B}=\mathrm{Cu}$. In the treatment with full solution the following descending order was observed regarding aerial part contents: $\mathrm{N}>\mathrm{K}>\mathrm{Ca}>\mathrm{P}>\mathrm{Mg}>\mathrm{S}$; in the roots: $\mathrm{N}>\mathrm{Ca}>\mathrm{Mg}>\mathrm{P}=\mathrm{S}$, and in the entire plant: $\mathrm{N}>\mathrm{K}>\mathrm{Ca}>\mathrm{P}>\mathrm{Mg}>\mathrm{S}$ (Table 4).

Similar results were reported by Bragança (2005) in Conilon coffee trees, with the following sequence of nutrients accumulation in leaves: $\mathrm{N}>\mathrm{Ca}>\mathrm{K}>\mathrm{Mg}>\mathrm{P}$, but only calcium extraction was higher than potassium in this study.

\section{Conclusions}

After studying the buildup of nutrients in plants and comparing them with the biological events involved in the development of the plant is possible to conclude that the omission of nutrients promotes nutritional disorders caused by both the direct effect of the nutrient as by the effect of the interaction among them. Still, several biological processes such as increasing the concentration of $\mathrm{CO}_{2}$ inside the plant and reducing the rate of net photosynthesis and stomata conductance are affected mainly by the omission of potassium and sulfur.

The dry matter production of roots is reduced by the omission of macronutrients, without exception, whereas only the omission of nitrogen and calcium was able to reduce the production of dry matter of the aerial part of the plant, these being the nutrients that most limited the total dry matter production of the crop.

This study on the omission of macronutrients in coffee plants, although simple, in practice it is possible to relate biological events involved with nutritional deficiency caused by nutrients poorly studied in the literature, such as calcium, magnesium and sulfur. 


\section{References}

Adams, F., B. L. Moore 1983. Chemical factors affecting root growth in subsoil horizons of coastal plain soils. Soil Science Society of American Journal, 47: 99-102.

AOAC (Association of Official Analytical Chemists). 1975. Official Methods of Analysis. 12th ed. Washington, DC: AOAC.

Barbosa, J. C., and W. Maldonado Jr. 2012. AgroEstat - Sistema de análises estatísticas de ensaios agronômicos [AgroEstat - Analysis System Statistics Agronomic Trials], Versão 1.0, Jaboticabal, Brazil: UNESP.

Braga, J. M., and B. V. Defelipo. 1974. Spectrophotometric P determination in soil and plant material. Revista Ceres 21: 73-85.

Bragança, S. M. 2005. Crescimento e acúmulo de nutrientes pelo cafeeiro Conilon (Coffea canéfora Pierre) [Growth and accumulation of nutrients by the coffee conilon]. Viçosa, Brazil: UFV.

Bragança, S. M., L. C. Prezotti, and J. A. Lani. 2007. Nutrição do cafeeiro Conilon [Nutrition of coffee Conilon]. In: Café Conilon, eds. R. G. Ferrão, A. F. A. Fonseca, S. M. Bragança, M. A. G. Ferrão, and L. H. Muner, pp. 299-327. Vitória, Brazil: Incaper.

Chalfoun, S. M., and P. R. Reis. 2010. História da cafeicultura no Brasil [History of coffee in Brazil]. In: Café Arábica: Do Plantio à Colheita [Coffee Arabica: From Planting to Harvest], eds. P. R. Reis, and R. L. Cunha, pp. 23-85. Lavras, Brazil: EPAMIG.

CONAB - Companhia Nacional de Abastecimento. 2014. Acompanhamento [Accompaniment]. Café: Primeira Estimativa [Coffee: First Estimate]. Brasília: CONAB.

Conway, W. S., and C. E. Sams. 1983. Calcium infiltration of Golden Delicious apples and its effect on decay. Phytopathology 73: 1068-1071.

Cruz, J. L., C. R. Pelacani, J. E. B. Carvalho, L. F. S. Souza Filho, and D. C. Queiroz. 2007. Nitrogen levels and photosynthetic rate of papaya 'golden'. Ciência Rural 37: 64-71.

dos Santos, U. M. Jr., J. F. C. Gonçalves, and T. R. Feldpausch. 2006. Growth, leaf nutrient concentration and photosynthetic nutrient use efficiency in tropical tree species planted in degraded areas in central Amazonia. Forest Ecology and Management 226: 299-309.

Epstein, E. 1975. Nutrição Mineral de Plantas: Princípios e Perspectivas [Mineral Nutrition of Plants: Principles and Perspectives]. Rio de Janeiro, Brazil: Livros Técnicos e Científicos.

Evans, H. J., and R. A. Wildes. 1971. Potassium and its role in enzyme activation. In: Proceedings $8^{\text {th }}$ Colloquium of the International Potash Institute.

Filgueira, F. A. R. 2003. Novo manual de olericultura: Agrotecnologia moderna na produção e comercialização de hortaliças [New manual of horticulture: Modern agro-technology in the production and marketing of vegetable]. Viçosa, Brazil: Universidade Federal de Viçosa.

Guimarães, P. T. G., and T. H. P. Reis. 2010. Nutrição e adubação do cafeeiro [Nutrition and fertilization of coffee]. In: Café Arábica: Do Plantio à Colheita [Coffee arabica: From planting to harvest], eds. P. R. Reis, and R. L. Cunha, pp. 343-414. Lavras, Brazil: EPAMIG.

Hanson, E. J., J. L. Beggs, and R. M. Beaudry. 1993. Applying calcium chloride postharvest to improve highbush blueberry firmness. HortScience 28: 1033-1034.

Heldt, H. W. 1997. Plant Biochemistry and Molecular Biology. New York: Oxford University.

Hoagland, D. R., and D. I. Arnon. 1950. The water culture method for growing plants without soils. Berkeley, CA: California Agricultural Experimental Station.

Jackson, M. L. 1958. Soil Chemical Analysis. Upper Saddle River, NJ: Prentice Hall.

Johnson, C. M., and A. Ulrich. 1959. Analytical Methods for Use in Plants Analyses. Los Angeles, CA: University of California.

Malavolta, E. 1989. ABC da Adubação [ABCs of Fertilization]. São Paulo, Brazil: Agronômica Ceres.

Malavolta, E. 2006. Manual de Nutrição Mineral de Plantas [Manual of Mineral Nutrition in Plants]. São Paulo: Editora Agronômica Ceres.

Malavolta, E., G. C. Vitti, and S. A. Oliveira. 1997. Avaliação do Estado Nutricional Das Plantas: Princípios e Aplicações [Evaluation of the nutritional status of plants: Principles and applications]. Piracicaba, Brazil: POTAFÓS.

Marschner, H. 1995. Mineral Nutrition of Higher Plants. London: Academic Press.

Martinez, H. E. P., A. V. Zabini, Y. P. Neves, J. M. Clemente, A. W. Pedrosa. 2008. Diagnose foliar em cafeeiro [Leaf analysis in coffee]. In: Nutrição de Plantas: Diagnose Foliar em Grandes Culturas [Plant Nutrition: Diagnose leaf in major crops], eds. R. M. Prado, D. E. Rozane, D. W. Vale, M. R. Correia, and H. A. Souza. pp. 267-301. Jaboticabal, Brazil: FCAV/CAPES/FUNDUNESP.

Mengel, K., and E. A. Kirkby. 1987. Principles of Plant Nutrition. Bern: International Potash Institute.

Passos, L. P. 1999. Fisiologia do capim-elefante: Uma revisão analítica [Elephant Grass physiology: A review]. In: Biologia e Manejo do Capim-Elefante [Elephant Grass Biology And Management], eds. L. P. Passos, L. A. Carvalho, and C. E. Martins, pp. 29-62. Juiz de Fora, Brazil: Embrapa Gado de Leite.

Pierce, J. 1986. Determinants of substrate specificity and the role of metal in the reaction of ribolosebisphosphate carboxylase/oxygenase. Plant Physiology 81: 943-945.

Prado, R. M. 2008. Nutrição de Plantas [Plant Nutrition]. São Paulo, Brazil: UNESP.

Rains, D. W. 1976. Mineral metabolism. In: Plant Biochemistry. eds. J. Bonner, and J. E. Varner. New York: Academic Press. 
Ricci, M. S. F., M. C. P. Neves, A. N. Nannetti, C. F. Moreira, E. L. Aguiar-Menezes, E. Silva, I. F. Caixeta, J. B. S. Araújo, M. A. A. Leal, M. C. Fernandes, P. S. Almeida, and S. Pedini. 2006. Cultivo do café orgânico [Cultivation of Organic Coffee]. Campina Grande, Brazil: Embrapa Agrobiologia: Sistemas de Produção. [Comunicado Técnico].

Rodrigues, L. R. F. 2002. Técnicas de cultivo hidropônico e de controle ambiental no manejo de pragas, doenças e nutrição vegetal em ambiente protegido [Techniques of hydroponics and environmental control in the management of pests, diseases and plant nutrition in a protected environment]. Jaboticabal, Brazil: FUNEP.

Schnug, V. E., S. Zahn, and H. Pissarek. 1985. Nährstoff-Versorgung von Kaffee-Pflanzungen (Coffea canephora var. robusta) [Nutrient supply of coffee plantations (Coffea canephora var. Robusta)]. Der Tropenlandwirt 86: 129-136.

van Raij, B. 2011. Fertilidade do Solo e Manejo De Nutrientes [Soil Fertility and Nutrient Management]. Piracicaba, Brazil: International Plant Nutrition Institute. 